\title{
INTEGRATED APPROACH TO THE ASSESSMENT OF THE QUALITY OF IMMUNOSTIMULATORY BEVERAGE "IMMUNO PLUS"
}

\author{
Nadya Dzyuba \\ Department of Restaurant and Health Food Technology \\ Odessa National Academy of Food Technologies \\ 112 Kanatna str., Odessa, Ukraine, 65039 \\ adya282@rambler.ru \\ Liubov Telezhenko \\ Department of Restaurant and Health Food Technology \\ Odessa National Academy of Food Technologies \\ 112 Kanatna str., Odessa, Ukraine, 65039 \\ telegenko@ukr.net \\ Liudmyla Valevskaya \\ Department of Grain Storage Technology \\ Odessa National Academy of Food Technologies \\ 112 Kanatna str., Odessa, Ukraine, 65039 \\ ludmila_valev@mail.ru \\ Elena Zemlyakova \\ Department of Restaurant and Health Food Technology \\ Odessa National Academy of Food Technologies \\ 112 Kanatna str., Odessa, Ukraine, 65039 \\ lena_zemlyakova_00@mail.ru
}

\begin{abstract}
Based on the methods of theoretical qualimetry there was carried out the complex assessment of the quality of immunostimulatory beverage "Immuno plus". The hierarchic structure of the properties of ready product, including the organoleptic and physicalchemical parameters and also the ones of food and biological value was presented. It was demonstrated, that the improvement of consistence, homogeneity and steadiness of beverage can be explained by gluten that acts as a hydrocolloid and consumers estimate the beverage quality according to these very parameters. The profiles of vitamin and mineral composition of immunostimulatory beverage "Immuno plus" and also the content of irreplaceable acids in it were presented.

The received complex parameter of the "Immuno plus" beverage quality proves the high quality of new product. The calculated competitiveness of enriched beverage is 1,5 higher comparing with the control sample. The calculations of competitiveness of the beverage of increased food and biological value according to the modeling method that includes the parameters of the product quality, information about the analogues of elaborated goods and principle of innovations were presented. It was established, that the immunostimulatory beverage "Immuno plus" can be competitive on the Ukrainian consumer market at the expanse of improvement of organoleptic parameters, increase of food fibers, vitamins and mineral substances content in it and also of the presence of prophylactic properties.
\end{abstract}

Keywords: complex assessment of quality, immunostimulatory beverage, quality parameters, prophylactic product.

\section{Introduction}

Food is the one of most important factors that determines population health. Last years the health status of Ukrainian population significantly worsened: motility as a result of cardio-vascular and cancer diseases, hyperlipidemia and obesity increased [1]. Consumption of food products, containing great number of animal fat and simple carbohydrates leads to the growth of excessive body mass and obesity. Thus the problem of insufficient amount of necessary macro- and micro-nutrients in food rations is urgent [2]. 
The food disorders among Ukrainian population are mainly conditioned by the crisis situation in production and processing of food raw material and food products, worsening of economic situation of the most part of Ukrainian population, its low purchasing ability.

The analysis of structure of food of Ukrainian population [3] at the modern stage demonstrates that the protein deficit in Ukrainian's food ration is up to $26 \%$. Because of protein lack, the protein deficiency develops in human organism that leads to the disorders of enzymes synthesis, pancreas and intestine functions, negative nitrogen balance, muscular atony, decrease of organism resistance to the pathogenic agents.

The study of demand of potential beverage consumers was realized by the questionnaire. The study was carried out in October-November of 2016 in Odessa city. The study included 300 persons (18-27 years old), of different sex, profession, economic and family status. According to the results of research, it was established, that $87 \%$ of interrogated respondents prefer high-protein milk beverages that is why elaboration and assessment of the quality of new immunostimulatory beverages with increased food and biological value is urgent.

\section{Materials and Methods}

The commodity assessment of "Immuno plus" beverage was realized to get the complex quality parameter that would represent the function of singular quality parameters. The complex commodity assessment takes into account all requirements to organoleptic, physical-chemical parameters, the ones of food and biological value, safety ones.

The milk whey was selected as a control sample, as a studied one - "Immuno plus" beverage.

The different hydrocolloids must be used to increase the stability of food system as a quality parameter. Among them the hydrocolloids of protein nature can be separated. The most interest is attracted by gluten - the product of hydrolysis of secondary collagen-containing fish raw material. Gluten is rich with deficit amino acids oxilysine and oxiproline that play an important role in formation of connective tissue fibers.

Gluten was received by the method of multistage alkaline hydrolysis as it was described in the patent for useful model [4]. Molecular mass and homogeneity of gluten were determined by electrophoretic technique in $15 \%$ polyacrylamide gel by Lemley method. Amino acid content of gluten macromolecule was determined on amino acid analyzer Hitachi L-8900 (Japan).

To increase the quality parameters of the beverage, optimization of its component content was realized. The inlay "search for solution" in MS Excel (WINDOWS-2010) was used for the modeling of receipt [5].

To determine the microbiological parameters of beverage, the inoculations of bacteria of colon bacillus group (SST 30726-2001), Salmonella bacteria (SSTC IDF 122C:2003) and S. Aureus (SST 30347-97) were carried out.

For qualimetric assessment of quality there was constructed the hierarchic structure of ready product properties, consisted of the following groups:

Group $\mathrm{P}_{1}$ - organoleptic parameters:

$-\mathrm{P}_{1.1}$ - appearance;

$-\mathrm{P}_{1.2}-$ color;

$-\mathrm{P}_{1.3}$ - flavor;

$-\mathrm{P}_{1.4}$ - smell;

$-\mathrm{P}_{1.5}$ - consistence;

$-\mathrm{P}_{1.6}$ - homogeneity.

Group $\mathrm{P}_{2}-$ physical-chemical parameters:

$-\mathrm{P}_{2.1}$ - mass share of carbohydrates;

$-\mathrm{P}_{2.2}-$ mass share of dry substances;

$-\mathrm{P}_{2.3}$ - active acidity.

Group $\mathrm{P}_{3}$ - food value parameters:

$-\mathrm{P}_{3.1}-$ mass share of food fibers;

$-\mathrm{P}_{3.2}$ - energetic value. 
Group $\mathrm{P}_{4}$ - biological value parameters:

$-\mathrm{P}_{4.1}$ - vitamins content $\left(\mathrm{P}_{4.1 .1}-\beta\right.$-carotene; $\mathrm{P}_{4.1 .2}-$ thiamine; $\mathrm{P}_{4.1 .3}-$ riboflavin; $\mathrm{P}_{4.1 .4}-$ niacin; $\mathrm{P}_{4.1 .5}-$ vitamin E);

$-\mathrm{P}_{4.2}-$ mineral substances content $\left(\mathrm{P}_{4.2 .1}-\right.$ sodium; $\mathrm{P}_{4.2 .2}-$ calcium; $\mathrm{P}_{4.2 .3}-$ magnesium; $\mathrm{P}_{4.2 .4}$ - phosphorus; $\mathrm{P}_{4.2 .5}$ - ferum);

$-\mathrm{P}_{4.3}$ - irreplaceable amino acids content $\left(\mathrm{P}_{4.3 .1}\right.$ - valine; $\mathrm{P}_{4.3 .2}-$ isoleucine; $\mathrm{P}_{4.3 .3}$ - leucine; $\mathrm{P}_{4.3 .4}$ - lysine; $\mathrm{P}_{4.3 .5}$ - methionine; $\mathrm{P}_{4.3 .6}$ - threonine; $\mathrm{P}_{4.3 .7}$ - tryptophan).

The intervals of changes of the values of organoleptic parameters $P_{1}$ were set as equal to 0-5 points:

$-0-1$ - very bad quality;

$-1-2$ - bad quality;

$-2-3$ - middle quality;

$-3-4$ - good quality;

$-4-5-$ perfect quality.

The control sample (milk whey) and "Immuno plus" beverage were selected for qualimetric assessment of the quality.

The whey was selected as a control, because it increases kidneys work and normalizes liver functions; stimulates intestine activity, is especially useful at diets; takes the excessive liquid out of organism, in such a way favoring the optimal elimination of slag and toxins; is useful at rheumatism, hypertonia, improves blood circulation and prevent atherosclerosis development; decreases inflammatory processes (on skin, mucosa, in stomach, in intestine); has calming effect on nervous system; very useful for pregnant women. Due to the complex effect on human organism, milk whey can act as an immune stimulator with high biological properties.

The formulas (1)-(5), that took into account the ponderability coefficients and relative parameters of quality were used for the formation of complex quality parameter.

Taking into account the importance of separate parameters, the functional dependence of complex quality parameter looks as following:

$$
\mathrm{K}_{0}=\mathrm{f}\left(\mathrm{M}_{\mathrm{i}} \cdot \mathrm{K}_{\mathrm{i}}\right)
$$

where $\mathrm{M}_{\mathrm{i}}-$ ponderability coefficient of singular parameters, which sum must be equal $1 ; \mathrm{K}_{\mathrm{i}}-$ assessment coefficient of these parameters.

$$
M_{3}=\frac{1}{N} \sum_{j=1}^{N} M_{i j}, i=1,2,3 \ldots n,
$$

where $\mathrm{M}_{\mathrm{i}}$ - arithmetic mean value of importance coefficient of $\mathrm{i}$-th quality parameter; $\mathrm{N}$ - number of experts; $M_{i j}$ - importance coefficient of $i$-th parameter, presented by $j$-th expert $(j=1,2,3 \ldots N)$.

The assessment of quality of relative parameters $\mathrm{P}_{\mathrm{i}}$ of the separate properties was realized using Harrington's graph of desirability function for the properties of groups $\mathrm{P}_{1}, \mathrm{P}_{2}, \mathrm{P}_{3}$. On Harrington's graph of desirability function on $\mathrm{X}$-axis that is a dimensionless scale, divided in separate uneven parts, were marked the number of points, given within the selected values by separate parameters. On y-axis were found the dimensionless assessments of the quality parameters of singular properties. Harrington's graph of desirability function $[6,7]$ provides five intervals of assessment with correspondent coded values: very well (perfectly) - 1,00...0,80; well - 0,80...0,63; satisfactory $-0,63 \ldots 0,37$; badly $-0,37 \ldots 0,20$; very badly $-0,20 \ldots 0,00$.

The estimation of relative parameters $\mathrm{P}_{\mathrm{i}}$ quality was carried out by the formulas:

$$
\begin{aligned}
& \mathrm{q}_{3}=\frac{\mathrm{P}_{\mathrm{i}}}{\mathrm{P}_{\text {ibas }}}, \\
& \mathrm{q}_{3}=\frac{\mathrm{P}_{\text {ibas }}}{\mathrm{P}_{\mathrm{i}}},
\end{aligned}
$$


where $\mathrm{P}_{\mathrm{i}}$ - value of $\mathrm{i}$-th parameter $(\mathrm{i}=1,2,3 \ldots \mathrm{n})$ of estimated production quality; $\mathrm{P}_{\mathrm{ibas}}$ - basic value of $\mathrm{i}$-th parameter; $\mathrm{n}$ - number of estimated parameters.

The value of formula (3) was selected, if the increase of the value of i-th quality parameter resulted in increase of production quality in whole; and on the contrary, the formula (4) was used, when the decrease of the value of i-th quality parameter resulted in increase of product quality in whole.

The quality is influenced by the different factors at all main stages of the production living cycle. The hierarchic structure of the properties of immunostimulatory beverage "Immuno plus", necessary for reliable assessment of their quality, was constructed (Fig. 1). It is expedient to separate the group of main functional properties (properties of production as the ones of product), specific (organoleptic) ones and the ones of reliability (microbiological) [8-11].

The algorithm of calculation of complex assessment of the quality $\left(\mathrm{K}_{0}\right)$ included the following stages:

- construction of hierarchic structure of the ready production properties;

- selection of the interval of changes of the values of parameters $\mathrm{P}_{\mathrm{i}}$ (from $\mathrm{P}_{\min }$ to $\mathrm{P}_{\max }$ or from $\mathrm{P}_{\text {bas }}$ to $\mathrm{P}_{\mathrm{et}}$ ) and selection of basic parameters $\mathrm{P}_{\text {bas}}$;

- selection and construction of the scale of dimension of the quality assessments (to reduce the units of measurement of separate properties to the one type);

- determination of relative parameters $\mathrm{q}_{\mathrm{i}}$;

- calculation of the quality assessment of the separate properties $\mathrm{K}_{\mathrm{i}}$ and relative parameters $\mathrm{q}_{\mathrm{i}}$;

- determination of the way of calculation of ponderability coefficient $\mathrm{M}_{\mathrm{i}}$;

- selection of the method of reduction of the quality assessments of separate properties $\mathrm{K}_{\mathrm{i}}$ and relative parameters $\mathrm{q}_{\mathrm{i}}$ in one to receive the complex quality assessment $\mathrm{K}_{0}$;

- calculation of the complex quality assessment $\mathrm{K}_{0}$.

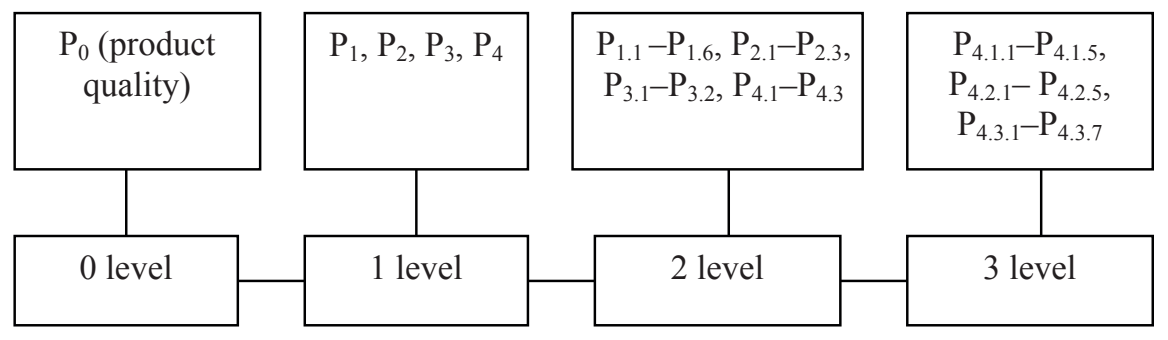

Fig. 1. Hierarchic structure of the properties of ready production

The competitiveness of received beverage "Immuno plus" was assessed by the modeling method [12], including the products quality parameters, information of analogs of elaborated goods, innovations principle. According to this method, there is a scale that takes into account the following elements:

- quality level;

- ponderability coefficient;

- quality parameters;

- characteristics of quality level;

- derivation of summary complex parameter of quality level and its use for the calculation of prospective competitiveness of the modeled innovative good;

- inclusion of calculations of the values in formula for reduction of the features of created innovative goods and analogues to the general conventional unit.

The formula was used for the calculation of beverage competitiveness:

$$
\mathrm{K}=\mathrm{P} \cdot \frac{\sum \mathrm{m}_{\mathrm{i}} \cdot \mathrm{g}_{\mathrm{i}}}{\mathrm{S}}
$$


where $\Sigma m_{i} g_{i}-$ summary complex parameter of quality level, expressed in points $\left(m_{i}-\right.$ ponderability coefficient and $\mathrm{g}_{\mathrm{i}}$ - quality parameter of $\mathrm{i}$-th property; $\mathrm{P}$ - price for unit of product; $\mathrm{S}$ - safety of product.

Safety of product at the calculation of competitiveness considers presence or absence of food additive, harmful for human, in it. As a result, the fraction is multiplied by 0 (the product is not competitive) or by 1 (the product has high competitiveness). The scale of quality assessment includes three levels [12]:

- good production (4 points) - competitive production with the highest values;

- satisfactory (3 points) - production that can compete with the best samples but not for a long time;

- bad production ( 2 points) - production that can be competitive only in nearest time, but not in future.

In connection with a fact that some quality parameters are considered as the main ones and other ones can be related to the secondary, the ponderability coefficient that must be divisible by 10 after summation was used for easy calculation.

\section{Results}

To determine the factors, influencing the ready product quality, the analysis of technology of product manufacturing at the modern enterprise was carried out. Fishbone diagram was constructed according to the received data.

According to the factors of the first level, there were established the ones of second level, given below the main ones with correspondent cipher. The series of facts are general in fabrication methods of any culinary production and their effect is taken into account already at the stage of enterprises designing. It was necessary to take into account the effect of all factors in technological process to improve the quality level. The secondary factors, specific at creation of quality level, determined the features of elaborated technologies; namely, elaboration of prophylactic products for elder people, sportsmen and children that need the special control of immunostimulatory beverage quality.

The collagenic preparation (gluten) that has a high content $(13 \ldots 15 \%)$ of rare amino acid hydroxyproline was used as a hydrocolloid-foam-former at immunostimulatory beverage production (Table 1).

Table 1

Receipt of the beverage, including the high content of immunostimulatory substances "Immuno plus"

\section{Components}

Apple juice, $\mathrm{cm}^{3}$

Whey, $\mathrm{cm}^{3}$

Pulp of hip, g

Banana puree, $\mathrm{g}$

Honey, g

Gluten, g

\section{Quantity}

The general assessment of "Immuno plus" beverage by organoleptic parameters is 29,3 points comparing with control, which general assessment - 27,6 points (Fig. 2). That is the enriched beverage, produced with gluten introduction exceeds control by $5,8 \%$. 


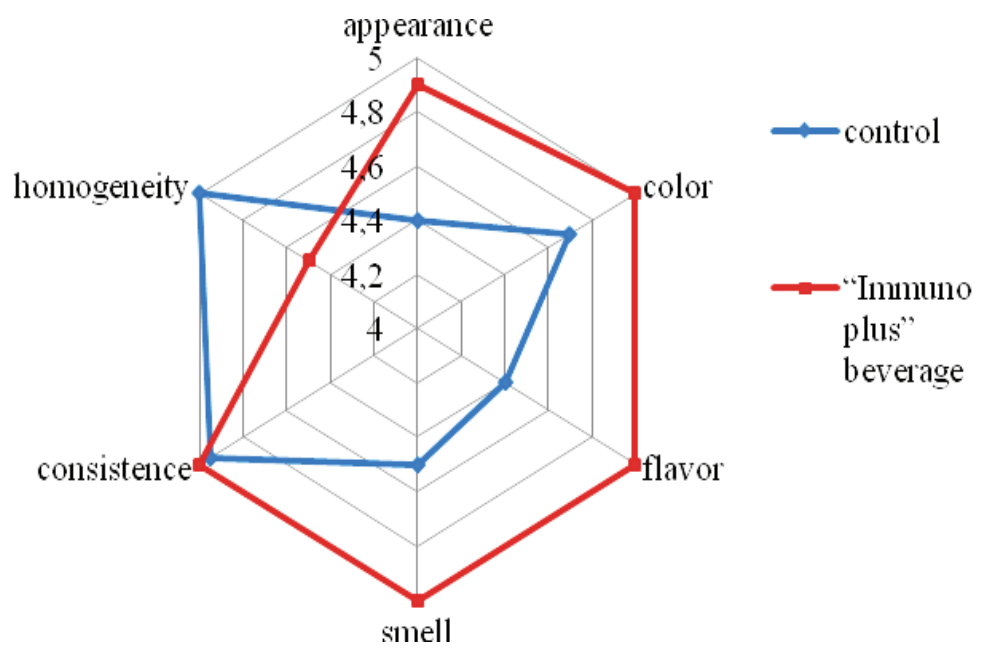

Fig. 2. Organoleptic profile of "Immuno plus" beverage

Microbiological parameters of "Immuno plus" beverage are presented in the Table 2.

Table 2

Microbiological parameters of "Immuno plus" beverage

\section{Parameters}

\section{Norm (SSTC 4552:2006)}

Not found (SST 30726-2001)

Not found (SSTC IDF 122C:2003)

As the basic parameters $\left(\mathrm{P}_{\text {bas }}\right)$ for beverage were selected the ones that correspond to the requirements of normative documentation for beverages (SSTC ISO 11816-1:2016). Table 3.

Relative quality parameters of control and "Immuno plus" beverage are presented in the

The profiles of vitamin and mineral content of elaborated beverage "Immuno plus" are presented on the Fig. 3.

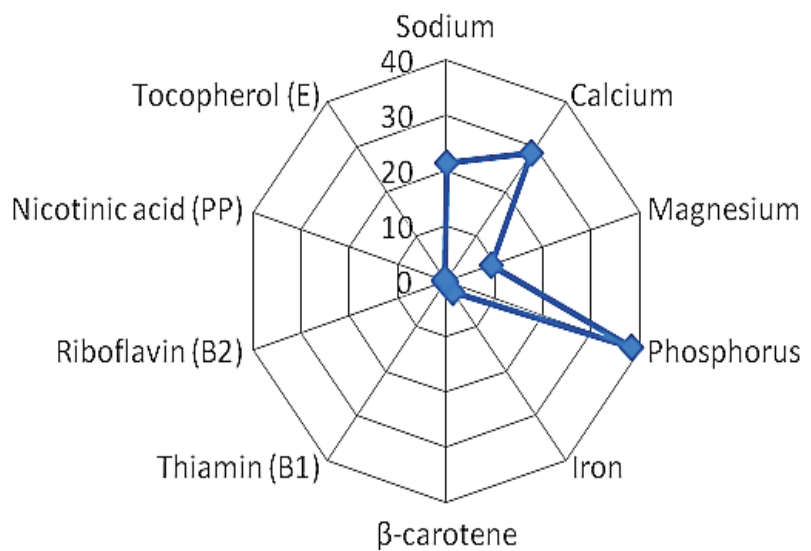

Fig. 3. Profile of the content of mineral substances and vitamins of beverage (mg/100 g) 
Table 3

Determination of relative quality parameters of control and "Immuno plus" beverage

\begin{tabular}{|c|c|c|c|c|c|c|}
\hline \multirow{2}{*}{$\begin{array}{c}\text { Units of } \\
\text { measurement }\end{array}$} & \multicolumn{3}{|c|}{ Quality parameters } & \multicolumn{3}{|c|}{ Relative quality parameters } \\
\hline & Symbol & Control & "Immuno plus" & Symbol & Control & "Immuno plus" \\
\hline \multirow{6}{*}{ Points } & $\mathrm{P}_{1.1}$ & 4,4 & 4,9 & $\mathrm{KP}_{1.1}$ & 0,86 & 0,96 \\
\hline & $\mathrm{P}_{1.2}$ & 4,4 & 5,0 & $\mathrm{KP}_{1.2}$ & 0,86 & 0,99 \\
\hline & $\mathrm{P}_{1.3}$ & 4,4 & 5,0 & $\mathrm{KP}_{1.3}$ & 0,86 & 0,99 \\
\hline & $\mathrm{P}_{1.4}$ & 4,5 & 5,0 & $\mathrm{KP}_{1.4}$ & 0,88 & 0,99 \\
\hline & $\mathrm{P}_{1.5}$ & 4,9 & 5,0 & $\mathrm{KP}_{1.5}$ & 0,96 & 0,99 \\
\hline & $\mathrm{P}_{1.6}$ & 5 & 4,4 & $\mathrm{KP}_{1.6}$ & 0,99 & 0,86 \\
\hline$\%$ & $\mathrm{P}_{2.1}$ & 1,5 & 2,5 & $\mathrm{KP}_{2.1}$ & 0,51 & 0,96 \\
\hline$\%$ & $\mathrm{P}_{2.2}$ & 3,0 & 5,0 & $\mathrm{KP}_{2.2}$ & 0,58 & 0,98 \\
\hline Unit $\mathrm{pH}$ & $\mathrm{P}_{2.3}$ & 2,0 & 4,5 & $\mathrm{KP}_{2.3}$ & 0,44 & 0,98 \\
\hline $\mathrm{g}$ & $\mathrm{P}_{3.1}$ & 0,20 & 0,9 & $\mathrm{KP}_{3.1}$ & 0,21 & 0,95 \\
\hline kcal & $\mathrm{P}_{3.2}$ & 63,0 & 77,28 & $\mathrm{KP}_{3.2}$ & 0,81 & 0,99 \\
\hline $\mathrm{mg}$ & $\mathrm{P}_{4.1 .1}$ & 0,05 & 0,18 & $\mathrm{KP}_{4.1 .1}$ & 0,27 & 0,97 \\
\hline $\mathrm{mg}$ & $P_{4.1 .2}$ & 0,06 & 0,19 & $\mathrm{KP}_{4.1 .2}$ & 0,31 & 0,97 \\
\hline $\mathrm{mg}$ & $\mathrm{P}_{4.1 .3}$ & 0,1 & 0,25 & $\mathrm{KP}_{4.1 .3}$ & 0,38 & 0,98 \\
\hline $\mathrm{mg}$ & $P_{4.1 .4}$ & 0,1 & 0,48 & $\mathrm{KP}_{4,1.4}$ & 0,20 & 0,98 \\
\hline $\mathrm{mg}$ & $P_{4.1 .5}$ & 0,12 & 0,41 & $\mathrm{KP}_{4.1 .5}$ & 0,29 & 0,98 \\
\hline $\mathrm{mg}$ & $\mathrm{P}_{4.2 .1}$ & 1,0 & 22,0 & $\mathrm{KP}_{4.2 .1}$ & 0,04 & 0,96 \\
\hline $\mathrm{mg}$ & $P_{4.2 .2}$ & 5,0 & 28,0 & $\mathrm{KP}_{4.2 .2}$ & 0,07 & 0,97 \\
\hline $\mathrm{mg}$ & $P_{4.2 .3}$ & 3,0 & 9,0 & $\mathrm{KP}_{4.2 .3}$ & 0,3 & 0,90 \\
\hline $\mathrm{mg}$ & $\mathrm{P}_{4.2 .4}$ & 2,0 & 37,0 & $\mathrm{KP}_{4.2 .4}$ & 0,05 & 0,97 \\
\hline $\mathrm{mg}$ & $\mathrm{P}_{4.2 .5}$ & 0,5 & 2,9 & $\mathrm{KP}_{4.2 .5}$ & 0,17 & 0,97 \\
\hline $\mathrm{mg}$ & $\mathrm{P}_{4.3 .1}$ & 0,2 & 0,83 & $\mathrm{KP}_{4.3 .1}$ & 0,24 & 0,99 \\
\hline $\mathrm{mg}$ & $\mathrm{P}_{4.3 .2}$ & 0,11 & 0,39 & $\mathrm{KP}_{4.3 .2}$ & 0,28 & 0,98 \\
\hline $\mathrm{mg}$ & $\mathrm{P}_{4.3 .3}$ & 0,10 & 0,80 & $\mathrm{KP}_{4.3 .3}$ & 0,12 & 0,94 \\
\hline $\mathrm{mg}$ & $P_{4.3 .4}$ & 0,20 & 1,70 & $\mathrm{KP}_{4.3 .4}$ & 0,12 & 0,99 \\
\hline $\mathrm{mg}$ & $\mathrm{P}_{4.3 .5}$ & 0,02 & 0,18 & $\mathrm{KP}_{4.3 .5}$ & 0,11 & 0,95 \\
\hline $\mathrm{mg}$ & $\mathrm{P}_{4.3 .6}$ & 0,12 & 0,59 & $\mathrm{KP}_{4.3 .6}$ & 0,20 & 0,98 \\
\hline $\mathrm{mg}$ & $P_{4.3 .7}$ & 0,01 & 0,17 & $\mathrm{KP}_{4.3 .7}$ & 0,10 & 0,94 \\
\hline
\end{tabular}


The study of vitamin content of "Immuno plus" beverage demonstrated the high content of vitamins-antioxidants. The introduction of hip pulp and banana puree favor the beverage enrichment with food fibers $(0,9 \mathrm{~g} / 100 \mathrm{~g})$, that in average covers $6 \ldots 18 \%$ of daily need. The use of gluten allows to receive a beverage, satisfying human need of protein in average by $7,57 \%$. The content of fats and carbohydrates is 0,2 and $12,02 \mathrm{~g} / 100 \mathrm{~g}$ respectively.

Energetic value of "Immuno plus" beverage is at that $77,28 \mathrm{kcal}$.

As it is demonstrated on the Fig. 3, the beverage "Immuno plus" contains such necessary substances for human organism as sodium, calcium, magnesium, phosphorus and iron. the Fig. 4.

The content of irreplaceable amino acids in "Immuno plus" beverage is presented on

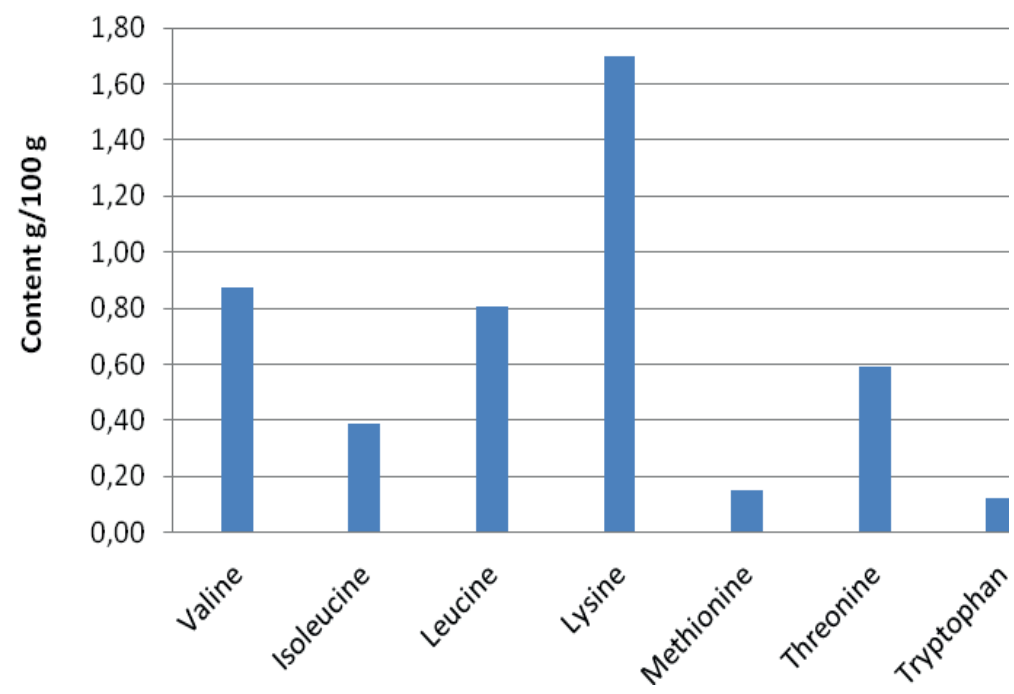

Fig. 4. Content of irreplaceable amino acids in "Immuno plus" beverage (g/100 g)

The notion of quality as a totality of all qualities that characterize production or technological process is used for the assessment of ready production and methods of its processing. The diversity of the methods of culinary production creation has its end use, the necessity of its assessment and ranking for revelation of most effective and prospective ones [13]. The assessment of culinary production quality is characterized by generalized parameter, where the complex quality parameter (CQP) is taken as optimization criterion. The calculation of CQP of elaborated "Immuno plus" beverage was realized according to the data of factually set singular parameters, transformed into dimensionless ones. The importance of parameters within each group and inter-group ones was given by the experts. According to their data, the importance coefficients of each parameter and inter-group ones were calculated. Having calculated the ponderability coefficients, their correspondence to the conditions was verified. The importance coefficients were calculated, according to the data of the Table 2:

$$
\begin{gathered}
\sum_{\mathrm{i}=1}^{6} \mathrm{MP}_{1}=0,2+0,1+0,2+0,1+0,2+0,2=1, \\
\sum_{\mathrm{i}=1}^{3} \mathrm{MP}_{2}=0,35+0,3+0,35=1, \\
\sum_{\mathrm{i}=1}^{2} \mathrm{MP}_{3}=0,5+0,5=1,
\end{gathered}
$$




$$
\begin{aligned}
& \sum_{\mathrm{i}=1}^{17} \mathrm{MP}_{4}=0,06+0,06+0,05+0,06+0,05+ \\
& +0,06+0,06+0,06+0,06+0,06+0,06+ \\
& +0,06+0,06+0,06+0,06+0,06+0,06=1 .
\end{aligned}
$$

To reduce the quality assessments of the separate properties together, the additive model of complex assessment as average weighted arithmetic values was accepted:

$$
\mathrm{K}_{0}=\sum_{\mathrm{i}=1}^{\mathrm{n}} \mathrm{M}_{\mathrm{i}} \cdot \mathrm{K}_{\mathrm{i}}
$$

where $\mathrm{M}_{\mathrm{i}}$ - importance coefficient of $\mathrm{i}$-th parameter; $\mathrm{K}_{\mathrm{i}}$ - relative quality coefficient.

For the group of organoleptic parameters:

$$
\begin{gathered}
\mathrm{KP}_{1}=\left(\mathrm{MP}_{1.1} \cdot \mathrm{KP}_{1.1}\right)+\left(\mathrm{MP}_{1.2} \cdot \mathrm{KP}_{1.2}\right)+\left(\mathrm{MP}_{1.3} \cdot \mathrm{KP}_{1.3}\right)+ \\
\quad+\left(\mathrm{MP}_{1.4} \cdot \mathrm{KP}_{1.4}\right)+\left(\mathrm{MP}_{1.5} \cdot \mathrm{KP}_{1.5}\right)+\left(\mathrm{MP}_{1.6} \cdot \mathrm{KP}_{1.6}\right) .
\end{gathered}
$$

For the control $\mathrm{KP}_{1}=0,71$, for the studied sample $\mathrm{KP}_{1}=0,76$.

For the group of physical-chemical parameters:

$$
\mathrm{KP}_{2}=\left(\mathrm{MP}_{2.1} \cdot \mathrm{KP}_{2.1}\right)+\left(\mathrm{MP}_{2.2} \cdot \mathrm{KP}_{2.2}\right)+\left(\mathrm{MP}_{2.3} \cdot \mathrm{KP}_{2.3}\right)
$$

For the control $\mathrm{KP}_{2}=0,507$, for the studied sample $\mathrm{KP}_{2}=0,973$.

For the group of food value parameters:

$$
\mathrm{KP}_{3}=\left(\mathrm{MP}_{3.1} \cdot \mathrm{KP}_{3.1}\right)+\left(\mathrm{MP}_{3.2} \cdot \mathrm{KP}_{3.2}\right)
$$

For the control $\mathrm{KP}_{3}=0,51$, for the studied sample $\mathrm{KP}_{3}=0,97$.

For the group of biological value parameters:

$$
\begin{gathered}
\mathrm{KP}_{4}=\left(\mathrm{MP}_{4.1 .1} \cdot \mathrm{KP}_{4.1 .1}\right)+\left(\mathrm{MP}_{4.1 .2} \cdot \mathrm{KP}_{4.1 .2}\right)+\left(\mathrm{MP}_{4.1 .3} \cdot \mathrm{KP}_{4.1 .3}\right)+ \\
+\left(\mathrm{MP}_{4.1 .4} \cdot \mathrm{KP}_{4.1 .4}\right)+\left(\mathrm{MP}_{4.1 .5} \cdot \mathrm{KP}_{4.1 .5}\right)+\left(\mathrm{MP}_{4.2 .1} \cdot \mathrm{KP}_{4.2 .1}\right)+ \\
+\left(\mathrm{MP}_{4.2 .2} \cdot \mathrm{KP}_{4.2 .2}\right)+\left(\mathrm{MP}_{4.2 .3} \cdot \mathrm{KP}_{4.2 .3}\right)+\left(\mathrm{MP}_{4.2 .4} \cdot \mathrm{KP}_{4.2 .4}\right)+ \\
+\left(\mathrm{MP}_{4.2 .5} \cdot \mathrm{KP}_{4.2 .5}\right)+\left(\mathrm{MP}_{4.3 .1} \cdot \mathrm{KP}_{4.3 .1}\right)+\left(\mathrm{MP}_{4.3 .2} \cdot \mathrm{KP}_{4.3 .2}\right)+ \\
+\left(\mathrm{MP}_{4.3 .3} \cdot \mathrm{KP}_{4.3 .3}\right)+\left(\mathrm{MP}_{4.3 .4} \cdot \mathrm{KP}_{4.3 .4}\right)+\left(\mathrm{MP}_{4.3 .5} \cdot \mathrm{KP}_{4.3 .5}\right)+ \\
+\left(\mathrm{MP}_{4.3 .6} \cdot \mathrm{KP}_{4.3 .6}\right)+\left(\mathrm{MP}_{4.3 .7} \cdot \mathrm{KP}_{4.3 .7}\right) .
\end{gathered}
$$

For the control $\mathrm{KP}_{4}=0,188$, for studied sample $\mathrm{KP}_{4}=0,966$.

The calculation of complex quality assessment of the immunostimulatory beverage "Immuno plus" is:

$$
\begin{gathered}
\mathrm{KP}_{0}=\left(\mathrm{MP}_{1} \cdot \mathrm{KP}_{1}\right)+\left(\mathrm{MP}_{2} \cdot \mathrm{KP}_{2}\right)+ \\
+\left(\mathrm{MP}_{3} \cdot \mathrm{KP}_{3}\right)+\left(\mathrm{MP}_{4} \cdot \mathrm{KP}_{4}\right) .
\end{gathered}
$$

The received data of complex quality assessment of the beverage "Immuno plus" are presented in the Table 4.

As far as a consumer at first pays attention to the organoleptic parameters and food value, these criteria of competitiveness received the higher ponderability coefficient (Table 5).

The results of calculation of competitiveness of the control sample and immunostimulatory beverage are given in the Table 6. 
Table 4

Complex quality assessment of the beverage "Immuno plus"

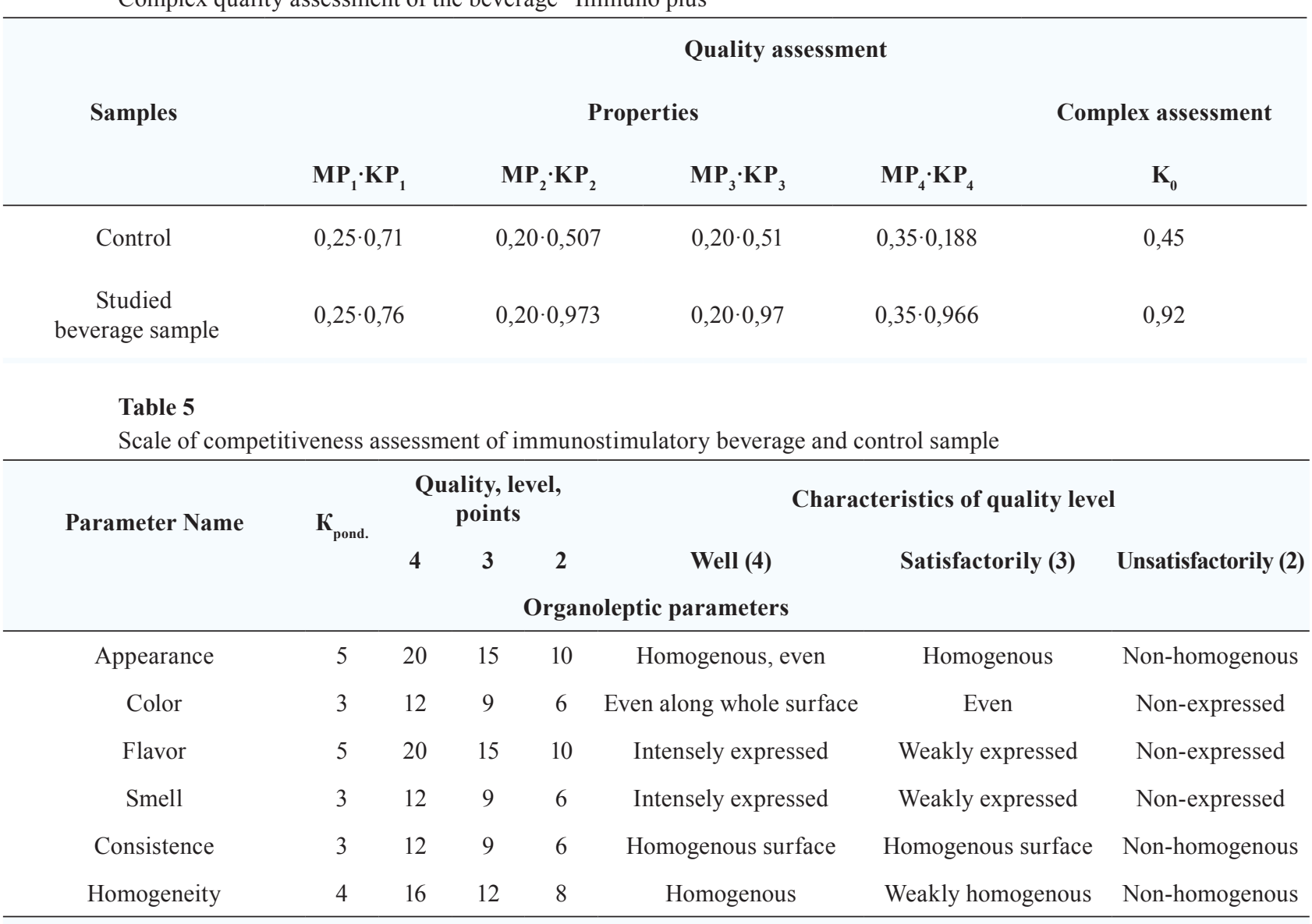

Physical-chemical parameters

\begin{tabular}{|c|c|c|c|c|c|c|c|}
\hline $\begin{array}{c}\text { Mass share of } \\
\text { carbohydrates, \% }\end{array}$ & 10 & 40 & 30 & 20 & No less 2,5 & $1 \ldots 2$ & less 1 \\
\hline $\begin{array}{l}\text { Mass share of } \\
\text { dry substances, } \\
\text { g/100 g of product }\end{array}$ & 5 & 20 & 15 & 10 & No less 5 & $2 \ldots 5$ & less 2 \\
\hline Active acidity & 10 & 40 & 30 & 20 & No less 4,5 & $3 \ldots 4,5$ & less 3 \\
\hline \multicolumn{8}{|c|}{ Food value parameters } \\
\hline Mass share of food fibers, $g$ & 9 & 36 & 27 & 18 & No less 0,9 & $0,9 \ldots 0,4$ & less 0,4 \\
\hline Energetic value, kcal & 10 & 40 & 30 & 20 & No more 80 & $60 \ldots 75$ & less 70 \\
\hline Prophylactic properties & 8 & 32 & 24 & 16 & Many directions & $3-4$ directions & 1-2 directions \\
\hline \multicolumn{8}{|c|}{ Innovative activity parameters } \\
\hline Receipt novelty & 10 & 40 & 30 & 20 & Protected by patent & Non-protected by patent & Absent \\
\hline \multicolumn{8}{|c|}{ Marketing studies parameters } \\
\hline Advertising & 7 & 28 & 21 & 14 & $\begin{array}{l}\text { TV, newspapers, } \\
\text { magazines, } \\
\text { external advertising }\end{array}$ & $\begin{array}{l}\text { newspapers, magazines, } \\
\text { external advertising }\end{array}$ & Absent \\
\hline Market analysis, demand & 8 & 32 & 24 & 16 & No rivals, high demand & $\begin{array}{l}\text { Weak competition, } \\
\text { high demand }\end{array}$ & $\begin{array}{l}\text { Strong competi- } \\
\text { tion, weak demand }\end{array}$ \\
\hline
\end{tabular}


Table 6

Competitiveness of the control sample and immunostimulatory beverage "Immuno plus"

\begin{tabular}{|c|c|c|c|c|c|c|}
\hline \multirow{3}{*}{ Parameter name } & \multirow{3}{*}{$\mathbf{K}_{\text {pond. }}$} & \multicolumn{3}{|c|}{ Quality level, points } & \multicolumn{2}{|c|}{ Assessment of samples } \\
\hline & & 4 & 3 & 2 & Control sample & "Immuno plus beverage" \\
\hline & & \multicolumn{5}{|c|}{ Organoleptic parameters } \\
\hline Appearance & 5 & 20 & 15 & 10 & 10 & 20 \\
\hline Color & 3 & 12 & 9 & 6 & 6 & 12 \\
\hline Flavor & 5 & 20 & 15 & 10 & 10 & 20 \\
\hline Smell & 3 & 12 & 9 & 6 & 6 & 12 \\
\hline Consistence & 3 & 12 & 9 & 6 & 6 & 12 \\
\hline Homogeneity & 4 & 16 & 12 & 8 & 12 & 12 \\
\hline
\end{tabular}

Physical-chemical parameters

\begin{tabular}{|c|c|c|c|c|c|c|}
\hline Mass share of carbohydrates, $\%$ & 10 & 40 & 30 & 20 & 20 & 40 \\
\hline $\begin{array}{l}\text { Mass share of dry substances, } \\
\text { g/100 } \mathrm{g} \text { of product }\end{array}$ & 5 & 20 & 15 & 10 & 15 & 20 \\
\hline Active acidity & 10 & 40 & 30 & 20 & 20 & 40 \\
\hline \multicolumn{7}{|c|}{ Food value parameters } \\
\hline Mass share of food fibers, $g$ & 9 & 36 & 27 & 18 & 18 & 36 \\
\hline Energetic value, kcal & 10 & 40 & 30 & 20 & 20 & 40 \\
\hline Prophylactic properties & 8 & 32 & 24 & 16 & 16 & 32 \\
\hline \multicolumn{7}{|c|}{ Innovative activity parameters } \\
\hline Receipt novelty & 10 & 40 & 30 & 20 & 20 & 40 \\
\hline \multicolumn{7}{|c|}{ Marketing studies parameters } \\
\hline Advertising & 7 & 28 & 21 & 14 & 14 & 21 \\
\hline Market analysis, demand & 8 & 32 & 24 & 16 & 16 & 32 \\
\hline Complex parameter of competitiveness & 100 & 400 & 300 & 200 & 209 & 389 \\
\hline Price for $100 \mathrm{ml}$ & $5,0 / 6,2$ & $5,0 / 6,2$ & $5,0 / 6,2$ & $5,0 / 6,2$ & 5,0 & 6,2 \\
\hline Competitiveness & $20 / 16,1$ & $80 / 64,5$ & $60 / 48,4$ & $40 / 32,3$ & 41,8 & 62,7 \\
\hline
\end{tabular}

\section{Conclusions}

1. On the base of technological studies the parameters, influencing production quality at its manufacturing were determined. Using Fishbone diagram, there was carried out the generalization of technological requirements to the production quality with further structurization. It was established, that the most important technological parameters are raw material, manufacturing technology and process regimes, applied equipment, staff qualification and duration of technological process realization. 
2. Optimization of the component content of "Immuno plus" beverage was carried out using the outlay "Search for solution" in MS Excel (WINDOWS-2010). The receipt of immunostimulatory beverage consists of apple juice, banana puree, honey, hip pulp, gluten. The data received at the study of the nutrient content of "Immuno plus" beverage give a possibility to state that this beverage is a source of easily assimilated macro- and micronutrients and can be used as immunostimulatory product. It was established, that at elaboration of "Immuno plus" beverage it is necessary to provide the immunostimulatory effect at the expanse of introduction of biologically active components of unconventional raw material.

3. The data, received at the competitiveness assessment of new product, demonstrated, that immunostimulatory beverage "Immuno plus" can be competitive on the Ukrainian consumer market.

4. The next stage of the work is the marketing study of Ukrainian market for presence of immunostimulatory beverages and also the transfer of technologies at the modern enterprises of restaurant economy.

\section{References}

[1] Dzyuba, N., Zemlyakova, E., Pedak, E. (2016). Foundations of balanced diet modeling in the disordered ecological situation. Zbirnuk naukovuh prats HDUHT, 1, 142-153.

[2] Lypovyi, D. V. (2016). Stvorennia funktsionalnykh produktiv kharchuvannia. Zbirnyk materialiv IX Vseukrainskoi naukovo-praktychnoi konferentsii molodykh uchenykh ta studentiv z mizhnarodnoiu uchastiu, 296.

[3] Telezhenko, L., Dzyuba, N., Kashkano, M. (2015). Instant porridge composition of the functional purpose: technological aspects. Journal of Food Science and Technology, 9 (4), 68-74. doi: 10.15673/2073$8684.4 / 2015.55874$

[4] Telezhenko, L. M., Kushnir, N. A. (25.04.2013). Process for producing collagen preparation. Patent of Ukraine No. 79357. MPK A23 J 1/04 (2006.01.01). Appl. No. u201209751. Filed 13.08.2012. Bull. No. 8. Available at: http://uapatents.com/5-79357-sposib-oderzhannya-kolagenovogo-preparatu.html

[5] Telezhenko, L. M., Dzyuba, N. A., Kashkano, M. A., Valevska, L. O. (2016). Osnovy naukovykh doslidzhen. Kherson: Hrin D.S., 192.

[6] Zharkov, Yu., Tsytsyliano, O. (2005). Systemy upravlinnia yakistiu: monitorynh roboty orhaniv z otsinky vidpovidnosti z vykorystanniam metodu Kharinhtona. Standartyzatsiia, sertyfikatsiia, yakist, 1, 24-27.

[7] Halychev, A. V. (1983). Prykladnue voprosu kvalymetryy. Yzd-vo standartov, 136.

[8] Baidakova, L. I., Baidakova, I. M., Koshchii, O. V. (2000). Otsinka konkurentospromozhnosti tovariv na Ukraini. Vymiriuvalna ta obchysliuvalna tekhnika v tekhnolohichnykh protsesakh, 4, 174-178.

[9] Roberfroid, M. (2005). Inulin-Type Fructans and the Intestinal Absorption of Minerals. InulinType Fructans. CRC Press, 402. doi: 10.1201/9780203504932.ch10

[10] Baidakova, I. M. (2010). Formuvannia konkurentospromozhnosti produktsii na osnovi pidvyshchennia yakosti. Tovaroznavchyi visnyk, 2, 24-30.

[11] Mardar, M. R. (2010). Kompleksna tovaroznavcha otsinka yakosti novykh vydiv ekstrudovanykh zernovykh produktiv pidvyshchenoi kharchovoi tsinnosti Zernovi produkty i kombikormy, 1, 19-22.

[12] Lebedev, E. V., Savvateev, E. V. (2002). Konkurentosposobnost ynnovatsyonnukh tovarov. Pyshchevaia promushlennost, 1, 16-17.

[13] Omelchenko, N. V., Huba, L. M. (2009). Rozrobka prohramy dlia vyznachennia kompleksnoho pokaznyka yakosti tovariv. Tovaroznavstvo ta innovatsii, 1, 2-7. 